\title{
Analysis of information disclosure about social investments by companies that declare themselves socially responsible
}

\author{
Carolina P. Novelini ${ }^{a}$; Mariana S. F. A. Fregonesi ${ }^{\mathrm{a}}$ \\ ${ }^{a}$ Universidade de São Paulo, Faculdade de Economia, Administração e Contabilidade de Ribeirão Preto.
}

\section{Article Info}

Article history:

Received: 1 May 2012

Accepted: 1 March 2013

Key words:

Environmental accounting practices

ISO 14001 certification

Agroindustry

Sustainability

Social accountability

\begin{abstract}
The research theme is social disclosure, that is, voluntary information disclosure involving community, environment, employees and clients. For this study, the community focus was chosen, that is, companies' investments in social projects will be studied. According to voluntary disclosure theory, companies are anxious to publish good news, but resistant to the disclosure of bad news. The aim in this research is to analyze social investment information disclosure by companies that declare themselves sustainable. Therefore, an empirical study was undertaken in 31 companies listed in the Corporate Sustainability Index (ISE) portfolio, applying content analysis to the parts on community involvement in the reports published. The results showed: none of the companies fully left out information about the objective of its projects; few companies disseminated the destination of investments in all projects; the sacrifice the companies made frequently was not clear; very little information is available about the use of tax benefits. More frequent disclosure of information with a more immediate positive impact was perceived.
\end{abstract}

Copyright $(\odot) 2013$ FEA-RP/USP. All rights reserved.

\section{INTRODUCTION}

Nowadays, a growing number of companies have been concerned with sustainable performance of their activities. Companies have been increasingly preoccupied with building an institutional image linked to the sustainability concept. In the eyes of end consumers, financial institutions' advertisements stand out, which do not sell a product (funding line, investment funds etc.), but the institution itself (sustainable, socially responsible bank).

Being sustainable refers to the ability to company with present liabilities without compromising the ability to perform one's activities in the future (Gri, 2006; Tinoco, 2010). This concept entails no harm to the environment and companies' involvement in affiliated communities. One cannot affirm whether companies' social investments in social and environmental projects have increased or whether companies, perceiving the value of the socio-environmental appeal, simply started to disclose that information. Nevertheless, information disclosure about socio-environmental investments

Corresponding author: Tel +551636023920

E-mail addresses: cpnovelini@fearp.usp.br (C.P. Novelini),mafregonesi@ usp.br (M. S. F. A. Fregonesi)

USP / FEARP - Av. Bandeirantes, 3900 - Monte Alegre -14040-900

Ribeirao Preto, SP - Brasil has visibly grown. To inform society, besides media disclosure, companies use their social balance sheets, aka annual or sustainability reports, which contain environmental, social and economic information. These reports are available online on the company websites.

Despite the existence of models or guidelines for the elaboration of these reports, companies are free to elaborate them as they wish, as this disclosure is voluntary.

This information may be audited or not and companies are free to disclose only that information they find convenient. According to the theory of voluntary information disclosure (Verrecchia, 2001), companies are anxious to publish good news, but resistant to the dissemination of bad news.

In this research, social disclosure is focused on, that is, voluntary information disclosure involving community, environment, employees and clients. For the sake of this study, the community focus was chosen, that is, companies' investments in social projects. The aim in this research is to analyze information disclosure about social investments by companies that declare themselves sustainable. More specifically, the focus is on whether information is provided about investment values, the way these investments were made and whether tax benefits were used. Therefore, an empirical study was undertaken in 31 companies listed in the Corporate Sustainability Index (ISE) portfolio of BMF\&Bovespa, applying content analysis to the reports published. What justifies this research is the relevance of this 
theme not only in the corporate context, but also for the Brazilian society as a whole. In general, no certification is attached to voluntary disclosure, entailing the need for certification by society. The latter is responsible for verifying the quality of social disclosure practices in Brazilian companies and for indicating what additional information should be published.

\section{THEORETICAL FRAMEWORK}

Sustainable development involves company management so that its economic, social and environmental activities are balanced and so that the interests of direct and indirect stakeholders are satisfied. Therefore, sustainability means performance based on these three pillars, and companies need to include them into internal Corporate Social Responsibility discussions (Branco; Rodrigues, 2006).

The Corporate Social Responsibility (CSR) idea includes social and environmental information disclosure about organizational practices. While some organizations publish their reports on a completely voluntary base, that is, without any legal requirements, others only disclose compulsory information, and yet others publish some date beyond regulatory demands (Gamerschlag; Möller; Verbeeten, 2010; Kim, 1993).

CSR amounts and actions can be published through different communication channels. The most frequent are annual reports, which concentrate different information types that are useful to distinct publics in a sole document, providing a general view of the organization's situation (Gray; Kouhy; Lavers, 1995).

Disclosure involves long-term benefits and shortterm costs, such as data collection for disclosure purposes or report audits, when a structure is needed that can sustain this relation (Branco; Rodrigues, 2006).

The most frequently published social disclosure items in annual reports are: community, clients, employees and environmental characteristics. Over time, however, new information sets are added to respond to each country and each company's needs to disclose what it finds most relevant, so that this structure is altered at the entity's convenience (Gray; Kouhy; Lavers, 1995).

As the reports functions as a vehicle between company and society, the publication of good news is accompanied by anxiety, while the disclosure of bad news arouses resistance. Hence, companies are responsible for the formation of their image, which is crucial to develop their reputation in society, keeping in mind that missing information sounds like negative information that was left out (Verrecchia, 2001; Hooghiemstra, 2000). The aim of disclosure is the reduction of political and social costs, making most companies publish information that causes no harm and transmits a positive image of their activities (Gamerschlag; Möller; Verbeeten, 2010; Dye, 2001).

To support voluntary information disclosure, Verrecchia (2001) expresses three disclosure theories, with the observation that no sole sufficiently comprehensive theory exists. These are: associationbased disclosure, judgment-based disclosure and efficiency-based disclosure. The first aims to analyze the effects of disclosure on investors' actions, considering price and business volume changes. In this theory, disclosure is characterized as exogenous. The second theory analyzes managers' discretionary power, as these have all information available for possible disclosure, selecting those items for inclusion in the report and considering disclosure as endogenous. The final theory aims to link efficiency with disclosure, considering that efficiency is the link with the strongest potential between disclosure and information asymmetry reduction (Verrecchia, 2001).

Differently from Verrecchia (2001), who believes that no truly comprehensive theory exists, which includes efficiency, influence of market processes and incentives, Dye (2001) defends that voluntary disclosure theory is sufficient to explain the theme. This theory reports that organizations publish favorable information and leave out unfavorable information.

According to Branco and Rodrigues (2006), a positive relation exists between social and environmental information disclosure and financial performance, as donation plans entail tax burden cuts, observing cost reductions. Another factor that proves this relation is that, as the company reveals its social responsibility, sales increase and the company builds or keeps up its reputation, which is a fundamental intangible resource for its continuity. The latter factors will only be relevant, however, if society grants due importance to social responsibility.

According to Kim (1993), better informed stockholders demand a lower disclosure level, while stockholders that do not have access to privileged information published or do not agree with the disclosure structure can put pressure on the disclosure level the organization is developing.

Therefore, the aim of voluntary social information disclosure is to minimize the costs of the relation between the company and society, similar to a compensation offered to society, in view of the negative activities the company is performing (Gamerschlag; Möller; Verbeeten, 2010).

In this perspective, social information disclosure is intended at neutralizing negative images published in the media or at reinforcing positive impacts, considering that no apology is due for negative impacts, given that the organization does not assume its error, but merely takes responsibility for the consequences (Hooghiemstra, 2000).

Nascimento et al. (2009) developed a bibliometrics study of social and environmental disclosure research submitted to English-language journals between 1997 and 2007 and surveyed the main theories used to sustain social and environmental disclosure. These are: institutional theory, stakeholder theory, legitimacy theory, political economy theory and the cross-cultural approach.

Institutional theory reveals that organizations are part of an environment with a range of influential variables, ranging from economic and human resource elements to cultural elements, which should receive proper attention (Scott, 1987; Nascimento Et Al. 2009; Rezende, 2009). To sustain this theory, Scott (1987) evidences the presence of isomorphism and distinguishes three types: cognitive, normative and regulatory. The first concentrates on mimetic characteristics, when companies hold others as their models. The second indicates the presence of technical and professional items, to turn into references of behavior and attitudes. The third indicates that companies adopt a certain behavior due to the presence 
of laws, standards and sanctions (Nascimento et al., 2009; Rezende, 2009).

Stakeholder theory evidences that all stakeholders are equally important, without any overlapping. Stakeholders are considered as all people or groups of people affected by company activities when it works to accomplish its objectives. Hence, the active relation with all stakeholders, and not only with stockholders, should be included in the organization's strategic planning (Freeman; McVea, 2000). This theory explains the fact that managers direct their activities to achieve the best results, considering that disclosure serves as a communication means between managers and stakeholders (Gray; Kouhy; Lavers, 1995).

Legitimacy theory is the most used to explain social disclosure (Hooghiemstra, 2000; Nascimento et al., 2009). According to that theory, environmental and social information disclosure takes place for the company to gain legitimacy in society (Deegan, 2002). It is a strategic aspect of disclosure as, if society believes that the organization is not operating acceptably, that is, is not complying with society's expectations, it is breaching its social contracts. Hence, companies attempt to work within socially established standards, and manipulation may take place for them to be able to achieve a stage of legitimacy (Deegan, 2002; Deegan; Rankin; Tobin, 2002; Nascimento et al. 2009).

According to the political economy theory of accounting, organizations should not only provide financial information, but also complement it through political, institutional and social data about the environment they are part of (Gray; Kouhy; Lavers, 1995).

The political economy of accounting is a theory based on the political economy discipline. This area is focused on the relation between economy, market and the State. As opposed to neoclassical economy, which emphasizes individual relations, departing from premises of human rationality, free from values, political economy studies the relation of economy in a broad political spectrum and engaged in a social assessment context. According to this discipline, the economic system cannot be analyzed when ignoring variables related to man's social activities (Nascimento et. al., 2009, p. 6).

Gamerschlag, Möller and Verbeeten (2010) use political cost theory to explain voluntary information disclosure. Political cost theory affirms that disclosure is done because it offers economic benefits to the organization, even if not directly, in the form of the prevention of taxes and regulatory actions. According to the authors, the main reasons affecting a company's willingness to publish information are: media attention (positively related); environment it is inserted in, with US companies disclosing more than German companies for example; number of stockholders (the more stockholders, the more information is disclosed); size (large companies disclose more information than small ones) and impact on society (companies like pollutant industries disclose more). Profitability, however, is a factor that only affects environmental information disclosure.

Some studies have analyzed socio-environmental information disclosure in Brazil. A first current in Brazilian research is related to compliance with disclosure standards. Leite Filho, Prates and Guimarães (2009) analyzed the disclosure level of six companies and found that, although their GRI reports are classified as $\mathrm{A}+$, they presented not even $50 \%$ of what the authors considered as ideal disclosure levels. In the same current, Boff et al. (2010) analyzed 23 company reports' compliance with the Brazilian accounting standard NBC T 15 and showed that $70 \%$ of the sample scored regular and insufficient concepts, while only $30 \%$ obtained good and excellent concepts. Costa and Marion (2007) analyzed environmental information disclosure and concluded that no uniformity exists between the information in the reports available on the BOVESPA website and the information companies publish on their official websites. Oliveira et al. (2009) analyzed the compliance of 39 companies' information disclosure with the indicators proposed by the United Nations (UN) and concluded that the most disseminated information is financial or present in any social reporting model, while the least disclosed information is not financial. It should be highlighted that, among the first most published indicators, the authors found voluntary contributions to civil society, focused on in this research.

In another Brazilian research current, socioenvironmental information disclosure is explained by relating disclosure levels with different factors. Conceição et al. (2011) analyzed 123 companies and showed that, in regulated companies, indebtedness, wealth distribution and tax components affect disclosure, while this influence could not be identified in non-regulated companies. Murcia and Souza (2009) analyzed the 100 largest companies listed on Bovespa and concluded that, with significance set at $10 \%$, seven variables explain for $48 \%$ of social and environmental disclosure: size, profitability, leverage, sector, internationalization, origin of control and sustainability, with leverage as the sole variable with an inverse relation. Cunha and Ribeiro (2008) investigated about 180 companies listed on Bovespa between 2003 and 2006 and concluded that social voluntary information disclosure is positively associated with the corporate governance level, performance, size and previous information disclosure.

Murcia, Santos and Souza (2009) analyzed the 100 largest companies on Bovespa and, although they did not assess information quality, but only the presence of that information, the study showed that 77 companies disclosed their spending on social projects. This study adds up to those authors' study, investigating the quality of information published about that spending.

\section{METHOD}

This research is characterized as an empirical study and is focused on companies that declare themselves socially responsible. Therefore, the researchers decided to analyze companies listed in the Corporate Sustainability Index (ISE). This index was set up by BM\&F BOVESPA and is aimed at listening the stock of companies with sustainable commitment. To be included in the index, companies need to initially answer a questionnaire on its socio-environmental actions on a voluntary base. Therefore, it is considered that the companies in that index classify themselves as socially responsible.

For data collection, the content analysis method was applied. The analysis was preferably focused on the sustainability report but, when this was not available, the annual report was used. The reports used in the research 
were taken from the organization's respective electronic addresses.

As this study is focused on the analysis of social investment information, the excerpt of community actions was chosen. Thus, in each report, that part was identified where actions are disseminate that involve society or the community. All reports used relate to 2010.

The empirical research was developed in two phases. In the first, each paragraph/figure/table was analyzed. The content analysis script was developed, including 13 yes/no questions about the information published, as well as five questions about the practice informed. In the second, the text was analyzed as a whole to analyze information disclosure.

Table 1 shows the companies listed in the ISE in 2009/2010, and which were therefore used for the study sample. Three of the companies listed - Dasa, Itaú S/A and Gerdau Met - were not used for the following reasons: the first does not publish its sustainability report/annual report on its website, so that the study object could not be identified; the second and third only publish the annual report of their holdings, and their controllers are already part of the sample, so that only the Annual Report of Itaú Unibanco and the Annual Report of Gerdau were analyzed.

Tab1e 1. ISE 2009/2010 portfolio with numbers used in this study and number of paragraphs analyzed

\begin{tabular}{r|l|r|l|r|l|r|l|r|r|r}
\hline 1 & Braskem (22) & 8 & Even (14) & 15 & AES Tietê (33) & 22 & INDS Romi (5) & 29 & Usiminas (40) \\
\hline 2 & Cemig (43) & 9 & Coelce (55) & 16 & Eletropaulo (72) & 23 & CPFL (37) & \multirow{2}{*}{ 30 Banco do Brasil (91) } \\
\hline 3 & BRF Foods (16) & 10 & Embraer (17) & 17 & Telemar (98) & 24 & Eletrobras (61) & \\
\hline 4 & Copel (32) & 11 & Itaú Unibanco (52) & 18 & Tractebel (27) & 25 & Duratex (14) & 31 & Cesp (42) \\
\hline 5 & Natura (11) & 12 & Suzano (42) & 19 & Redecard (11) & 26 & EDP (67) & 0 & Dasa \\
\hline 6 & Gerdau (12) & 13 & Tim Part. (35) & 20 & LIGHT (45) & 27 & Fibria (105) & 0 & Itaú S/A \\
\hline 7 & SulAmérica (22) & 14 & Sabesp (44) & 21 & Bradesco (36) & 28 & Vivo (36) & 0 & Gerdau Met \\
\hline
\end{tabular}

\section{RESULT ANALYSIS}

Among the 31 companies analyzed, out of 1236 paragraphs that address relations with society, 90.3\% actually refer to the companies' social responsibility practices. The company TIM is highlighted, which publishes 35 paragraphs about relations with society in its report, but does not disclose social responsibility practices in $34.3 \%$ of these. On the opposite, in the companies BRF Foods, Copel, Sabesp, Bradesco and Duratex, $100 \%$ of the paragraphs analyzed are related to social responsibility practices. As the analysis is focused on social responsibility reports, and specifically on the excerpt about the relation with society, $100 \%$ of the paragraphs were expected to address the theme. It should be mentioned that most of the paragraphs that did not discuss the theme presented company products, not related to CSR.

After analyzing the text's link with social responsibility, the link with social investments was verified. In this study, social investments are considered as resources spent on projects directed towards society. Out of 1116 paragraphs related to social responsibility practices, $90 \%$ are related to information about investments made. The companies Even and Copel stand out. In the first, out of 14 paragraphs analyzed, $45.5 \%$ do not reveal data about investments made. In the second, among 32 paragraphs analyzed, $43.8 \%$ do not reveal information about the investments made. Also, in two companies, $100 \%$ of the paragraphs publish investment information, i.e. Embraer and Redecard.

Thus, 1007 paragraphs address the research theme and will be analyzed, considering different criteria. The first question is aimed at understanding whether the companies disclose their investments in general, that is, whether they do not distinguish what project the resource was applied in when publishing data about their investment, or whether their disclosure is directed at specific projects. It was verified that $82.4 \%$ of the paragraphs present information about specific projects. INDS Romi is highlighted, which only published five paragraphs, all of which relate to its investments in general. Other highlights are Telemar and Even, which disclose information about their specific projects in $100 \%$ of the paragraphs analyzed, permitting a detailed understanding of each project the company is involved in. It was evidenced that disclosing investments according to specific projects improves the quality of the information and even permits investigating the project beneficiary. Also, specific information can lead to general information, but not the opposite.

A problem previously observed in social reports is that companies invest in a project in a given year and, in subsequent years, again includes the project in the report, without any new investments or clarifications. Therefore, the next question is aimed at understanding whether the period in which the investment was made is disclosed, which can be the reporting period or not, or whether no reference whatsoever is made to the period when the investment was concretized. The fact that $48.7 \%$ of the paragraphs analyzed do not contain any reference to the investment period is not necessarily bad, as one paragraph about the project would be sufficient to present this information. It could be observed, however, that $44.1 \%$ of the paragraphs relate to investments made in the reporting period.

Then, the number of beneficiaries the social investment reached was inquired. Once again, it is not necessarily bad that $77.7 \%$ of the paragraphs analyzed did not inform about the number of beneficiaries from the social projects, as one paragraph about the project would be sufficient. It should be highlighted, however, that the companies Even and INDS Romi do not disclose this information in any of the paragraphs analyzed.

Perhaps the first idea that comes to mind when considering investments is the amount invested. This 
question is aimed at getting to know the disclosure level of the social investment values. Disclosure of this type of information is very limited, as amounts are expressed in only $17.5 \%$ of the paragraphs analyzed.

And the second idea related to investments may be "in what". Therefore, the disclosure level about the project objectives was focused on. Information can be oriented towards specific projects, detailing the project developed or company projects as a whole, disclosing the main values the company heeds. In the latter case, the company may focus on more than one objective, entailing multiple objectives. Among 1007 paragraphs, $82.1 \%$ inform about the objectives of the social investments. It is interesting to observe that, in this respect, none of the companies totally left out the objective of its projects. This can be explained by legitimacy theory, as disclosing investment objectives is an indirect form of showing return to society.

Graph 1 shows how information about the objectives of the investments made is distributed. When informed, the objectives were divided as follows: education and qualification; sports; health; environmental education; arts and culture; social inclusion; conscious use of public goods; benefits to clients and assistential entities; resettlement projects; multiple and others. The item 'multiple', showing the highest incidence levels, was marked in case of more than one explicit objective and generally refers to when companies are treating their investments globally. Among specific objectives, the highest incidence level was for education and professional qualification, with $18.6 \%$ of the paragraphs analyzed.

Graph 1. Social investment objectives informed by companies

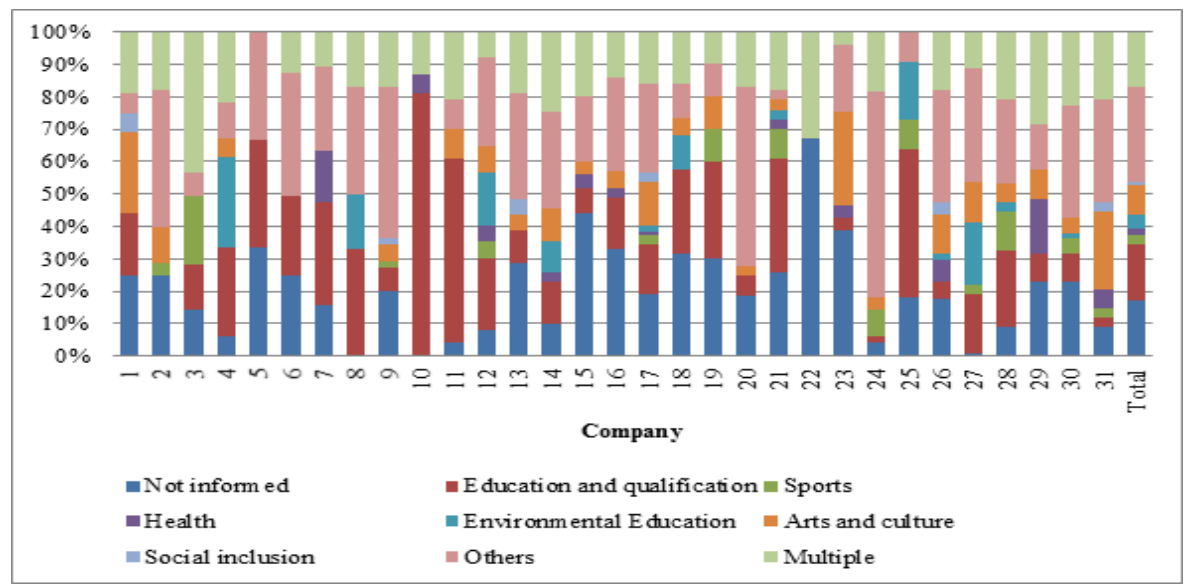

OBS. Table 1 in the Appendix displays the figures related to this distributio

It is very common for companies to invest through service sector entities. They can create their own foundations or choose an organization they trust. When companies do that, it is important to be concerned with the image the institution transmits to society. Therefore, the aim of the following question was to investigate whether the companies inform the destination of their investment, that is, whom they deliver the resources to. In general, the companies do not disclose this type of information, as only $26.5 \%$ of the paragraphs analyzed contain this disclosure. The company Itaú Unibanco
S/A is highlighted, which publishes the destination of its resources in $95.7 \%$ of the paragraphs analyzed, justified by the use of its own institutions, affiliated with the company brand, Fundação Itaú Social, Instituto Unibanco and Instituto Itaú Cultural. Graph 2 shows the distribution of the observations found. Again, the item 'multiple' is referent to the disclosure of more than one destination in the same paragraph. Resources for affiliated philanthropic entities are highlighted, representing $14 \%$ of the paragraphs that disclose information about investment destinations.

Graph 2. Social investment destinations informed by the companies

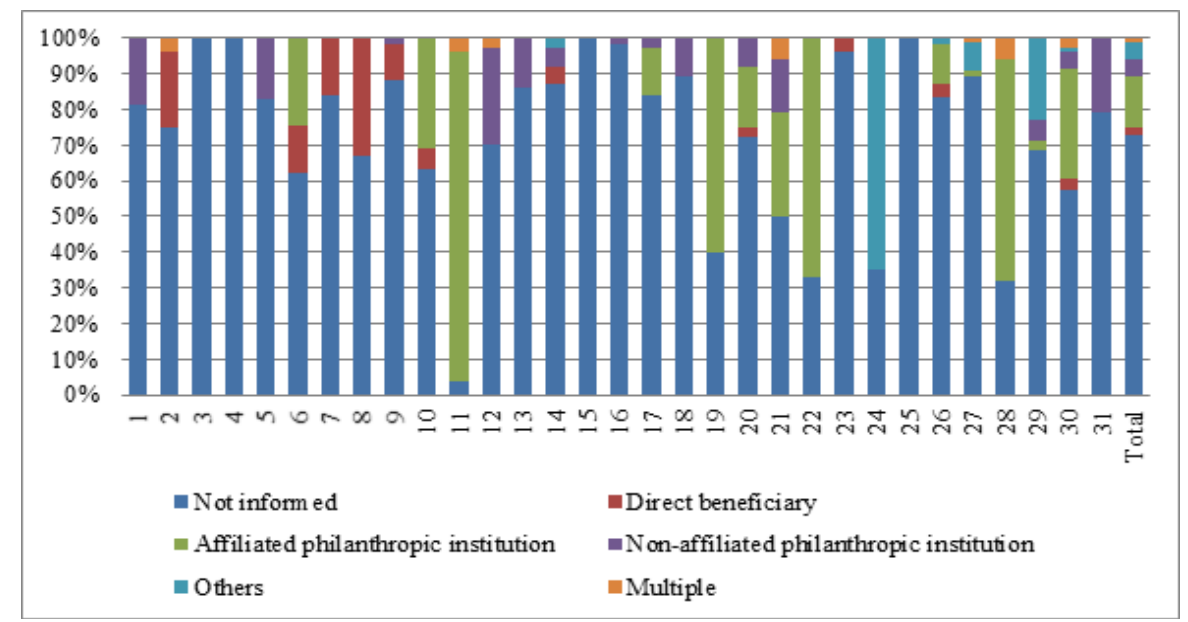

OBS. Table 2 in the Appendix displays the figures related to this distribution 
Making social investments necessarily involves a sacrifice for the company. Organizations can participate in all actions related to a social project or simply assume the costs to transport a group of company volunteers who undertake social actions in their free time. Very different sacrifices can take up the same space in investment disclosure. Hence, the next question was aimed at identifying whether the company discloses its actual sacrifice and what this refers to. In $87.8 \%$ of the paragraphs, no information is provided about the means to put the investment in practice. Moreover, $22.5 \%$ of all companies do not publish this type of information in any of its paragraphs.

Graph 3 shows what means are used to put the investment in practice, that is, the company's sacrifice, distinguishing: asset delivery, action delivery, service delivery, volunteering - when it is clear what benefits employees were offered in exchange for being a volunteer, volunteering - when no information is provided about what advantages employees received in exchange for their work, or others. Although the disclosure is very limited, the most used means to put investments in practice was through service delivery $(4.1 \%)$. Electric energy companies stand out, which generally deliver services to reduce tariffs for low-income clients or assist non-for-profit entities by installing equipment to reduce electric energy consumption. Volunteering also stands out with $6.6 \%$ of the paragraphs, half of which with and half without clear affiliation with the company.

Graph 3. Social investment means informed by the companies

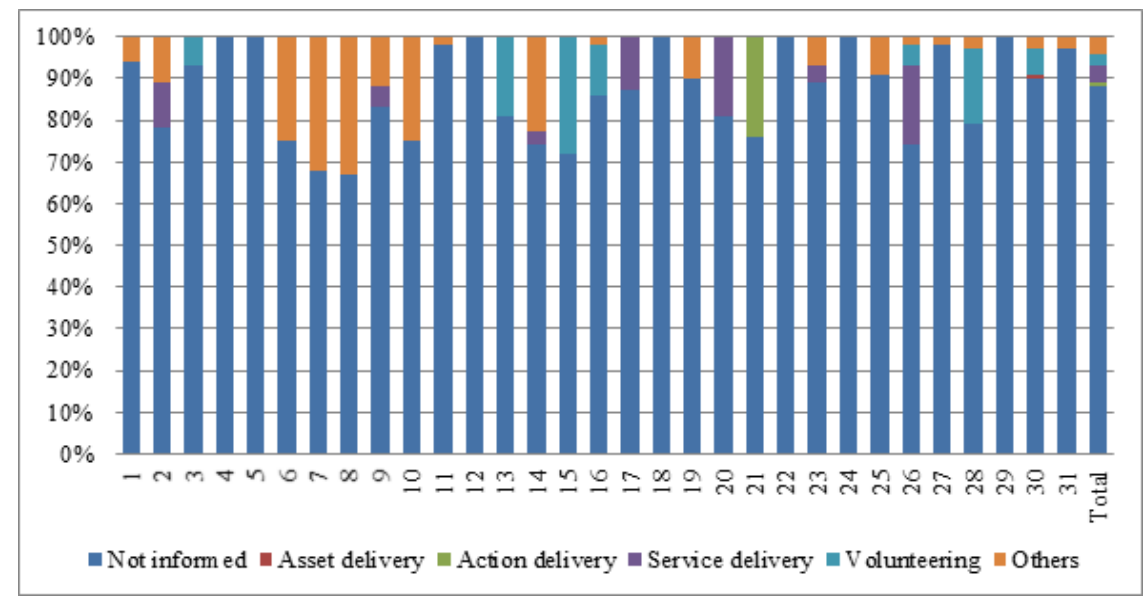

OBS. Table 3 in the Appendix displays the figures related to this distribution

Finally, to understand a social investment, two questions are important, the format of the investment (donation, sponsorship, collection campaign etc.) and the use of tax benefits. As regards the format, it helps to clarify the company's involvement in the social action and the resulting return for the company image. Format aspects are disclosed in $37 \%$ of the paragraphs analyzed. Graph 4 shows format disclosure and reveals that sponsorships are the most used format (5.6\%).

Graph 4 . Social investment format informed by the companies

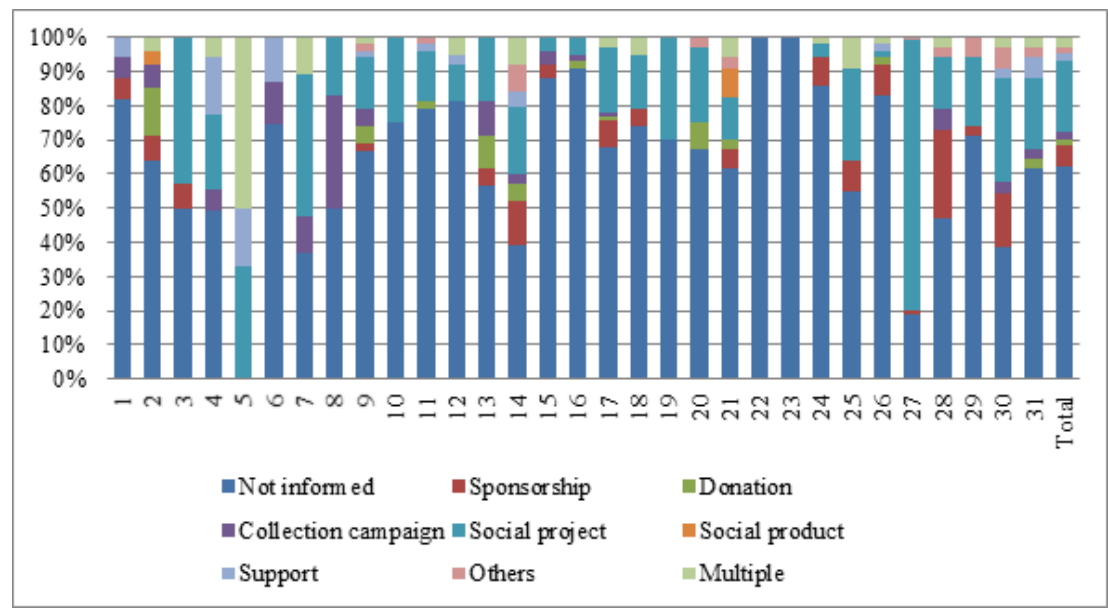

OBS. Table 4 in the Appendix contains the figures related to this distribution

Finally, disclosure on the use of tax benefits in the social investments was analyzed. This is disclosed in only $6.8 \%$ of the paragraphs analyzed. Only $33.8 \%$ of these disclose the amount of the tax benefit. In approximately $50 \%$ of the sample companies, no information whatsoever is published about tax benefit amounts. Also, among the companies that do disclose the use of tax benefits, $64.7 \%$ inform about the type of incentive (Culture Incentive Law, Sports Incentive Law etc.). 


\section{FINAL CONSIDERATIONS}

The aim in this research was to analyze information disclosure about social investments made by companies that declare themselves sustainable. Information was analyzed from 31 companies listed in the ISE portfolio on BMF\&Bovespa in the year the reports were collected. Applying content analysis to that part of the 2010 sustainability or annual reports about relations with society / community, published information could be analyzed about social investment amounts, use of tax benefits and about the sacrifice the company had made to develop the social action.

The results showed that $82.4 \%$ of the paragraphs contain information about specific projects, that is, the companies focus more on the projects than on generic information, relating to the company as a whole. This is positive, as investment disclosure per specific project improves information quality, and even permits investigating the project beneficiary.

As regards the beneficiaries, $22.3 \%$ of the paragraphs presented information about the volume of beneficiaries from the social projects, although two companies do not address the number of beneficiaries at any time.

The objective of the social project was disclosed in $82.1 \%$ of the paragraphs. In this respect, none of the companies fully left out the objective of its projects. This can be explained by legitimacy theory, disclosing investment objectives as an indirect way of showing return to society.

In general, companies did not publish the destination of investments in all projects. Entities with their own institutions, whose name is linked with the company brand, represented an exception, including Fundação Itaú Social, Instituto Unibanco and Instituto Itaú Cultural.

The sacrifice the company made was not clear in all projects either. To give an example, the disclosure of corporate volunteering projects is common. To constitute a social investment, however, the sacrifice should take the form of company assets, and not just employee efforts. In this respect, $22.5 \%$ of all companies do not disclosure this type of information in any of its paragraphs.

As to the use of tax incentives, very little information is available, particularly in monetary terms. When information is published, however, companies usually mention the project linked to the benefit received.

Companies aim to maximize stockholder gains and, no matter which theory is used, to justify the social investment, efforts will be made for the invested amount to benefit the company image and sales revenues. Hence, in compliance with the theory of voluntary disclosure, companies should prioritize information that brings "good news". In fact, the reports clearly revealed that information with a more immediate positive impact is the most disseminated. To give an example, a lot is published about investment objectives and corporate foundations, but little about the assets the company delivers and about the use of tax incentives.

Future studies can not only broaden the sample, but also compare the results found with disclosure in other countries. It would be interesting to replicate the study with companies listed in the Dow Jones Sustainability Index for example.

\section{REFERENCES}

Boff, M. L. et al. (2010). Adequação da Evidenciação Social das Empresas de Capital Aberto no Relatório da Administração e Notas Explicativas às Recomendações da NBC $\mathrm{T}$ 15. Revista de Contabilidade e Organizações, Ribeirão Preto, 4(8), 47-68. Recuperado em 25 de abril de 2012, de $<$ http://www.rco.usp.br/index.php/rco/article/ view/76/131>

Bolsa de Valores de São Paulo - Bovespa. Índice de sustentabilidade empresarial. Recuperado em 26 de janeiro, 2012, de http://www.bmfbovespa.com.br .

Branco, M. \& Rodrigues, L. (2006). Corporate Social Responsibility and Resource-Based Perspectives. Journal of Business Ethics, 69, 111-132.

Conceição, S. H. et al. (2011). Fatores determinantes no disclosure em Responsabilidade Social Corporativa (RSC):um estudo qualitativo e quantitativo com empresas listadas na Bovespa. Gest.Prod, São Carlos, 18(3), 461-472.

Costa, R. S. \& Marion, J. C. (2007). A Uniformidade na Evidenciação das Informações Ambientais. Revista Contabilidade e Finanças, São Paulo, 43, 20 - 33.

Cunha, J. V. A. \& Ribeiro, M. S. (2008). Divulgação voluntária de informações de natureza social: um estudo nas empresas brasileiras. Revista de Administração da USP Eletrônica, São Paulo, 1(1), art.6.

Deegan, C. (2002). The legitimizing effect of social and environmental disclosures - a theorical foundation. Accounting, Auditing \& Accountability Journal $(A A A J), 15(3), 282-311$.

Deegan, C.; Rankin, M. \& Tobin, J. (2002). An examination of the corporate social and environmental disclosures of BHP from 1983-1997. Accounting, Auditing \& Accountability Journal (AAAJ) 15(3), 312-343

Dye, R. (2001). An evaluation of 'essays on disclosure' and the disclosure literature in accounting. Journal of Accounting and Economics, 32, 181-235.

Freeman, R. E. \& Mcvea, J. A (2000). stakeholder approach to strategic management. In: Hitt, M., Freeman, E. \& Harrison, J. Handbook of strategic management. Oxford: Blackwell Publishing, 189207.

Gamerschlag, R.; Möller, K. \& Verbeeten, F. (2011). Determinants of voluntary CSR disclosure: empirical evidence from Germany. Review of Managerial Science, 5, 233-262.

Gray, R.; Kouhy, R. \& Lavers, S. (1995). Corporate social and environmental reporting: a review of the literature and a longitudinal study of UK disclosure. Accounting, Auditing and Accountability Journal (AAAJ), 8, 47-77.

Gray, R.; Kouhy, R. \& Lavers, S. (1995). Methodological themes: constructing a research database of social and environmental reporting by UK companies. Accounting, Auditing and Accountability Journal (AAAJ), 8, 78-101

Global Reporting Initiative- GRI. Diretrizes para relatório de sustentabilidade 2006. Recuperado em 25 de janeiro, 2012, de http://www.globalreporting. org. 
Hooghiemstra, R. (2000). Corporate Communication and Impression Management - New Perspectives Why Companies Engage in Corporate Social Reporting. Journal of Business Ethics, 27, 55-68.

Kim, O. (1993). Disagreements among shareholders over a firm's disclosure policy. The Journal of Finance, 48, 747-760

Leite Filho, G. A.; Prates, L. A. \& Guimarães, T. N. (2009). Análise os Níveis de Evidenciação dos Relatórios de Sustentabilidade das Empresas Brasileiras A+ do Global Reporting Initiative (GRI) no Ano De 2007. Revista de Contabilidade e Organizações, Ribeirão Preto, 3(7), 43-59. Recuperado em 25 de abril de 2012, de <http://www.rco.usp.br/index.php/rco/ article/view/107/95>.

Murcia, F. D. \& Souza, F. C (2009). Discretionary-based disclosure: the case of social and environmental reporting in Brazil. In: Congresso USP, 9., 2009, São Paulo. Anais... São Paulo: USP.

Murcia, F. D. \& Souza, F. C (2009). Social and environmental disclosure practices of brazilian companies. In: Congresso AnpCont, 3., 2009, São Paulo. Anais...São Paulo: Iaarr-Anpcont.

Nascimento, A. et al. (2009). Disclosure social e ambiental: análise das pesquisas científicas veiculadas em periódicos de língua inglesa. Revista Contabilidade Vista \& Revista, 20, 15-40.

Oliveira, M. C. et al. (2009). Divulgação de informações sociais por empresas brasileiras segundo os indicadores de responsabilidade social corporativa da ONU. Revista Contabilidade e Finanças, São Paulo, 20(51), 116-132.

Rezende, A. (2009). Um estudo sobre o processo de desinstitucionalização das práticas contábeis de correção monetária em empresas brasileiras. Tese - Faculdade de Economia, Administração e Contabilidade, Universidade de São Paulo, São Paulo.

Scott, W. R. (1987). The Adolescence of Institutional Theory. Administrative Science Quarterly, 32, 493511.

Tinoco, J. E. P. (2010). Balanço social e o relatório da sustentabilidade. São Paulo: Atlas.

Verrecchia, R. (2001). Essays on disclosure. Journal of Accounting and Economics, 32, 97-1801. 


\section{APPENDIX}

Table 2. Analysis of paragraphs according to objectives of social investments informed

\begin{tabular}{|c|c|c|c|c|c|c|c|c|c|c|}
\hline Company & $\begin{array}{c}\text { Not } \\
\text { informed }\end{array}$ & $\begin{array}{l}\text { Education } \\
\text { and } \\
\text { qualification }\end{array}$ & Sports & Health & $\begin{array}{l}\text { Environmental } \\
\text { Education }\end{array}$ & $\begin{array}{c}\text { Arts and } \\
\text { culture }\end{array}$ & $\begin{array}{c}\text { Social } \\
\text { inclusion }\end{array}$ & Others & Multiple & Total \\
\hline 1 & $25 \%$ & $19 \%$ & $0 \%$ & $0 \%$ & $0 \%$ & $25 \%$ & $6 \%$ & $6 \%$ & $19 \%$ & $100 \%$ \\
\hline 2 & $25 \%$ & $0 \%$ & $4 \%$ & $0 \%$ & $0 \%$ & $11 \%$ & $0 \%$ & $43 \%$ & $18 \%$ & $100 \%$ \\
\hline 3 & $14 \%$ & $14 \%$ & $21 \%$ & $0 \%$ & $0 \%$ & $0 \%$ & $0 \%$ & $7 \%$ & $43 \%$ & $100 \%$ \\
\hline 4 & $6 \%$ & $28 \%$ & $0 \%$ & $0 \%$ & $28 \%$ & $6 \%$ & $0 \%$ & $11 \%$ & $22 \%$ & $100 \%$ \\
\hline 5 & $33 \%$ & $33 \%$ & $0 \%$ & $0 \%$ & $0 \%$ & $0 \%$ & $0 \%$ & $33 \%$ & $0 \%$ & $100 \%$ \\
\hline 6 & $25 \%$ & $25 \%$ & $0 \%$ & $0 \%$ & $0 \%$ & $0 \%$ & $0 \%$ & $38 \%$ & $13 \%$ & $100 \%$ \\
\hline 7 & $16 \%$ & $32 \%$ & $0 \%$ & $16 \%$ & $0 \%$ & $0 \%$ & $0 \%$ & $26 \%$ & $11 \%$ & $100 \%$ \\
\hline 8 & $0 \%$ & $33 \%$ & $0 \%$ & $0 \%$ & $17 \%$ & $0 \%$ & $0 \%$ & $33 \%$ & $17 \%$ & $100 \%$ \\
\hline 9 & $20 \%$ & $7 \%$ & $2 \%$ & $0 \%$ & $0 \%$ & $5 \%$ & $2 \%$ & $46 \%$ & $17 \%$ & $100 \%$ \\
\hline 10 & $0 \%$ & $81 \%$ & $0 \%$ & $6 \%$ & $0 \%$ & $0 \%$ & $0 \%$ & $0 \%$ & $13 \%$ & $100 \%$ \\
\hline 11 & $4 \%$ & $57 \%$ & $0 \%$ & $0 \%$ & $0 \%$ & $9 \%$ & $0 \%$ & $9 \%$ & $21 \%$ & $100 \%$ \\
\hline 12 & $8 \%$ & $22 \%$ & $5 \%$ & $5 \%$ & $16 \%$ & $8 \%$ & $0 \%$ & $27 \%$ & $8 \%$ & $100 \%$ \\
\hline 13 & $29 \%$ & $10 \%$ & $0 \%$ & $0 \%$ & $0 \%$ & $5 \%$ & $5 \%$ & $33 \%$ & $19 \%$ & $100 \%$ \\
\hline 14 & $10 \%$ & $13 \%$ & $0 \%$ & $3 \%$ & $10 \%$ & $10 \%$ & $0 \%$ & $30 \%$ & $25 \%$ & $100 \%$ \\
\hline 15 & $44 \%$ & $8 \%$ & $0 \%$ & $4 \%$ & $0 \%$ & $4 \%$ & $0 \%$ & $20 \%$ & $20 \%$ & $100 \%$ \\
\hline 16 & $33 \%$ & $16 \%$ & $0 \%$ & $3 \%$ & $0 \%$ & $5 \%$ & $0 \%$ & $29 \%$ & $14 \%$ & $100 \%$ \\
\hline 17 & $19 \%$ & $15 \%$ & $3 \%$ & $1 \%$ & $2 \%$ & $13 \%$ & $3 \%$ & $27 \%$ & $16 \%$ & $100 \%$ \\
\hline 18 & $32 \%$ & $26 \%$ & $0 \%$ & $0 \%$ & $11 \%$ & $5 \%$ & $0 \%$ & $11 \%$ & $16 \%$ & $100 \%$ \\
\hline 19 & $30 \%$ & $30 \%$ & $10 \%$ & $0 \%$ & $0 \%$ & $10 \%$ & $0 \%$ & $10 \%$ & $10 \%$ & $100 \%$ \\
\hline 20 & $19 \%$ & $6 \%$ & $0 \%$ & $0 \%$ & $0 \%$ & $3 \%$ & $0 \%$ & $56 \%$ & $17 \%$ & $100 \%$ \\
\hline 21 & $26 \%$ & $35 \%$ & $9 \%$ & $3 \%$ & $3 \%$ & $3 \%$ & $0 \%$ & $3 \%$ & $18 \%$ & $100 \%$ \\
\hline 22 & $67 \%$ & $0 \%$ & $0 \%$ & $0 \%$ & $0 \%$ & $0 \%$ & $0 \%$ & $0 \%$ & $33 \%$ & $100 \%$ \\
\hline 23 & $39 \%$ & $4 \%$ & $0 \%$ & $4 \%$ & $0 \%$ & $29 \%$ & $0 \%$ & $21 \%$ & $4 \%$ & $100 \%$ \\
\hline 24 & $4 \%$ & $2 \%$ & $8 \%$ & $0 \%$ & $0 \%$ & $4 \%$ & $0 \%$ & $63 \%$ & $18 \%$ & $100 \%$ \\
\hline 25 & $18 \%$ & $45 \%$ & $9 \%$ & $0 \%$ & $18 \%$ & $0 \%$ & $0 \%$ & $9 \%$ & $0 \%$ & $100 \%$ \\
\hline 26 & $18 \%$ & $5 \%$ & $0 \%$ & $7 \%$ & $2 \%$ & $12 \%$ & $4 \%$ & $35 \%$ & $18 \%$ & $100 \%$ \\
\hline 27 & $1 \%$ & $18 \%$ & $3 \%$ & $0 \%$ & $19 \%$ & $12 \%$ & $0 \%$ & $35 \%$ & $11 \%$ & $100 \%$ \\
\hline 28 & $9 \%$ & $24 \%$ & $12 \%$ & $0 \%$ & $3 \%$ & $6 \%$ & $0 \%$ & $26 \%$ & $21 \%$ & $100 \%$ \\
\hline 29 & $23 \%$ & $9 \%$ & $0 \%$ & $17 \%$ & $0 \%$ & $9 \%$ & $0 \%$ & $14 \%$ & $29 \%$ & $100 \%$ \\
\hline 30 & $23 \%$ & $9 \%$ & $5 \%$ & $0 \%$ & $1 \%$ & $5 \%$ & $0 \%$ & $35 \%$ & $23 \%$ & $100 \%$ \\
\hline 31 & $9 \%$ & $3 \%$ & $3 \%$ & $6 \%$ & $0 \%$ & $24 \%$ & $3 \%$ & $32 \%$ & $21 \%$ & $100 \%$ \\
\hline Total & $17 \%$ & $17 \%$ & $3 \%$ & $2 \%$ & $4 \%$ & $9 \%$ & $1 \%$ & $29 \%$ & $17 \%$ & $100 \%$ \\
\hline
\end{tabular}


Table 3. Paragraph analysis according to destinations of social investments informed

\begin{tabular}{|c|c|c|c|c|c|c|c|}
\hline Company & Not informed & $\begin{array}{c}\text { Direct } \\
\text { beneficiary }\end{array}$ & $\begin{array}{c}\text { Affiliated } \\
\text { philanthropic } \\
\text { institution }\end{array}$ & $\begin{array}{c}\text { Non-affiliated } \\
\text { philanthropic } \\
\text { institution }\end{array}$ & Others & Multiple & Total \\
\hline 1 & $81 \%$ & $0 \%$ & $0 \%$ & $19 \%$ & $0 \%$ & $0 \%$ & $100 \%$ \\
\hline 2 & $75 \%$ & $21 \%$ & $0 \%$ & $0 \%$ & $0 \%$ & $4 \%$ & $100 \%$ \\
\hline 3 & $100 \%$ & $0 \%$ & $0 \%$ & $0 \%$ & $0 \%$ & $0 \%$ & $100 \%$ \\
\hline 4 & $100 \%$ & $0 \%$ & $0 \%$ & $0 \%$ & $0 \%$ & $0 \%$ & $100 \%$ \\
\hline 5 & $83 \%$ & $0 \%$ & $0 \%$ & $17 \%$ & $0 \%$ & $0 \%$ & $100 \%$ \\
\hline 6 & $63 \%$ & $13 \%$ & $25 \%$ & $0 \%$ & $0 \%$ & $0 \%$ & $100 \%$ \\
\hline 7 & $84 \%$ & $16 \%$ & $0 \%$ & $0 \%$ & $0 \%$ & $0 \%$ & $100 \%$ \\
\hline 8 & $67 \%$ & $33 \%$ & $0 \%$ & $0 \%$ & $0 \%$ & $0 \%$ & $100 \%$ \\
\hline 9 & $88 \%$ & $10 \%$ & $0 \%$ & $2 \%$ & $0 \%$ & $0 \%$ & $100 \%$ \\
\hline 10 & $63 \%$ & $6 \%$ & $31 \%$ & $0 \%$ & $0 \%$ & $0 \%$ & $100 \%$ \\
\hline 11 & $4 \%$ & $0 \%$ & $91 \%$ & $0 \%$ & $0 \%$ & $4 \%$ & $100 \%$ \\
\hline 12 & $70 \%$ & $0 \%$ & $0 \%$ & $27 \%$ & $0 \%$ & $3 \%$ & $100 \%$ \\
\hline 13 & $86 \%$ & $0 \%$ & $0 \%$ & $14 \%$ & $0 \%$ & $0 \%$ & $100 \%$ \\
\hline 14 & $88 \%$ & $5 \%$ & $0 \%$ & $5 \%$ & $3 \%$ & $0 \%$ & $100 \%$ \\
\hline 15 & $100 \%$ & $0 \%$ & $0 \%$ & $0 \%$ & $0 \%$ & $0 \%$ & $100 \%$ \\
\hline 16 & $98 \%$ & $0 \%$ & $0 \%$ & $2 \%$ & $0 \%$ & $0 \%$ & $100 \%$ \\
\hline 17 & $84 \%$ & $0 \%$ & $13 \%$ & $3 \%$ & $0 \%$ & $0 \%$ & $100 \%$ \\
\hline 18 & $89 \%$ & $0 \%$ & $0 \%$ & $11 \%$ & $0 \%$ & $0 \%$ & $100 \%$ \\
\hline 19 & $40 \%$ & $0 \%$ & $60 \%$ & $0 \%$ & $0 \%$ & $0 \%$ & $100 \%$ \\
\hline 20 & $72 \%$ & $3 \%$ & $17 \%$ & $8 \%$ & $0 \%$ & $0 \%$ & $100 \%$ \\
\hline 21 & $50 \%$ & $0 \%$ & $29 \%$ & $15 \%$ & $0 \%$ & $6 \%$ & $100 \%$ \\
\hline 22 & $33 \%$ & $0 \%$ & $67 \%$ & $0 \%$ & $0 \%$ & $0 \%$ & $100 \%$ \\
\hline 23 & $96 \%$ & $4 \%$ & $0 \%$ & $0 \%$ & $0 \%$ & $0 \%$ & $100 \%$ \\
\hline 24 & $35 \%$ & $0 \%$ & $0 \%$ & $0 \%$ & $65 \%$ & $0 \%$ & $100 \%$ \\
\hline 25 & $100 \%$ & $0 \%$ & $0 \%$ & $0 \%$ & $0 \%$ & $0 \%$ & $100 \%$ \\
\hline 26 & $84 \%$ & $4 \%$ & $11 \%$ & $0 \%$ & $2 \%$ & $0 \%$ & $100 \%$ \\
\hline 27 & $89 \%$ & $0 \%$ & $2 \%$ & $0 \%$ & $8 \%$ & $1 \%$ & $100 \%$ \\
\hline 28 & $32 \%$ & $0 \%$ & $62 \%$ & $0 \%$ & $0 \%$ & $6 \%$ & $100 \%$ \\
\hline 29 & $69 \%$ & $0 \%$ & $3 \%$ & $6 \%$ & $23 \%$ & $0 \%$ & $100 \%$ \\
\hline 30 & $58 \%$ & $3 \%$ & $31 \%$ & $5 \%$ & $1 \%$ & $3 \%$ & $100 \%$ \\
\hline 31 & $79 \%$ & $0 \%$ & $0 \%$ & $21 \%$ & $0 \%$ & $0 \%$ & $100 \%$ \\
\hline Total & $73 \%$ & $2 \%$ & $14 \%$ & $5 \%$ & $5 \%$ & $1 \%$ & $100 \%$ \\
\hline
\end{tabular}


Table 4. Analysis of paragraphs according to social investment means informed

\begin{tabular}{|c|c|c|c|c|c|c|c|}
\hline Company & $\begin{array}{c}\text { Not } \\
\text { informed }\end{array}$ & $\begin{array}{c}\text { Asset } \\
\text { delivery }\end{array}$ & $\begin{array}{l}\text { Action } \\
\text { delivery }\end{array}$ & Service delivery & Volunteering & Others & Total \\
\hline 1 & $94 \%$ & $0 \%$ & $0 \%$ & $0 \%$ & $0 \%$ & $6 \%$ & $100 \%$ \\
\hline 2 & $79 \%$ & $0 \%$ & $0 \%$ & $11 \%$ & $0 \%$ & $11 \%$ & $100 \%$ \\
\hline 3 & $93 \%$ & $0 \%$ & $0 \%$ & $0 \%$ & $7 \%$ & $0 \%$ & $100 \%$ \\
\hline 4 & $100 \%$ & $0 \%$ & $0 \%$ & $0 \%$ & $0 \%$ & $0 \%$ & $100 \%$ \\
\hline 5 & $100 \%$ & $0 \%$ & $0 \%$ & $0 \%$ & $0 \%$ & $0 \%$ & $100 \%$ \\
\hline 6 & $75 \%$ & $0 \%$ & $0 \%$ & $0 \%$ & $0 \%$ & $25 \%$ & $100 \%$ \\
\hline 7 & $68 \%$ & $0 \%$ & $0 \%$ & $0 \%$ & $0 \%$ & $32 \%$ & $100 \%$ \\
\hline 8 & $67 \%$ & $0 \%$ & $0 \%$ & $0 \%$ & $0 \%$ & $33 \%$ & $100 \%$ \\
\hline 9 & $83 \%$ & $0 \%$ & $0 \%$ & $5 \%$ & $0 \%$ & $12 \%$ & $100 \%$ \\
\hline 10 & $75 \%$ & $0 \%$ & $0 \%$ & $0 \%$ & $0 \%$ & $25 \%$ & $100 \%$ \\
\hline 11 & $98 \%$ & $0 \%$ & $0 \%$ & $0 \%$ & $0 \%$ & $2 \%$ & $100 \%$ \\
\hline 12 & $100 \%$ & $0 \%$ & $0 \%$ & $0 \%$ & $0 \%$ & $0 \%$ & $100 \%$ \\
\hline 13 & $81 \%$ & $0 \%$ & $0 \%$ & $0 \%$ & $19 \%$ & $0 \%$ & $100 \%$ \\
\hline 14 & $75 \%$ & $0 \%$ & $0 \%$ & $3 \%$ & $0 \%$ & $23 \%$ & $100 \%$ \\
\hline 15 & $72 \%$ & $0 \%$ & $0 \%$ & $0 \%$ & $28 \%$ & $0 \%$ & $100 \%$ \\
\hline 16 & $86 \%$ & $0 \%$ & $0 \%$ & $0 \%$ & $12 \%$ & $2 \%$ & $100 \%$ \\
\hline 17 & $88 \%$ & $0 \%$ & $0 \%$ & $13 \%$ & $0 \%$ & $0 \%$ & $100 \%$ \\
\hline 18 & $100 \%$ & $0 \%$ & $0 \%$ & $0 \%$ & $0 \%$ & $0 \%$ & $100 \%$ \\
\hline 19 & $90 \%$ & $0 \%$ & $0 \%$ & $0 \%$ & $0 \%$ & $10 \%$ & $100 \%$ \\
\hline 20 & $81 \%$ & $0 \%$ & $0 \%$ & $19 \%$ & $0 \%$ & $0 \%$ & $100 \%$ \\
\hline 21 & $76 \%$ & $0 \%$ & $24 \%$ & $0 \%$ & $0 \%$ & $0 \%$ & $100 \%$ \\
\hline 22 & $100 \%$ & $0 \%$ & $0 \%$ & $0 \%$ & $0 \%$ & $0 \%$ & $100 \%$ \\
\hline 23 & $89 \%$ & $0 \%$ & $0 \%$ & $4 \%$ & $0 \%$ & $7 \%$ & $100 \%$ \\
\hline 24 & $100 \%$ & $0 \%$ & $0 \%$ & $0 \%$ & $0 \%$ & $0 \%$ & $100 \%$ \\
\hline 25 & $91 \%$ & $0 \%$ & $0 \%$ & $0 \%$ & $0 \%$ & $9 \%$ & $100 \%$ \\
\hline 26 & $74 \%$ & $0 \%$ & $0 \%$ & $19 \%$ & $5 \%$ & $2 \%$ & $100 \%$ \\
\hline 27 & $98 \%$ & $0 \%$ & $0 \%$ & $0 \%$ & $0 \%$ & $2 \%$ & $100 \%$ \\
\hline 28 & $79 \%$ & $0 \%$ & $0 \%$ & $0 \%$ & $18 \%$ & $3 \%$ & $100 \%$ \\
\hline 29 & $100 \%$ & $0 \%$ & $0 \%$ & $0 \%$ & $0 \%$ & $0 \%$ & $100 \%$ \\
\hline 30 & $90 \%$ & $1 \%$ & $0 \%$ & $0 \%$ & $6 \%$ & $3 \%$ & $100 \%$ \\
\hline 31 & $97 \%$ & $0 \%$ & $0 \%$ & $0 \%$ & $0 \%$ & $3 \%$ & $100 \%$ \\
\hline Total & $88 \%$ & $0 \%$ & $1 \%$ & $4 \%$ & $3 \%$ & $4 \%$ & $100 \%$ \\
\hline
\end{tabular}


Table 5. Analysis of paragraphs according to social investment format informed

\begin{tabular}{|c|c|c|c|c|c|c|c|c|c|c|}
\hline Company & $\begin{array}{c}\text { Not } \\
\text { informed }\end{array}$ & Sponsorship & Donation & $\begin{array}{l}\text { Collection } \\
\text { campaign }\end{array}$ & $\begin{array}{l}\text { Social } \\
\text { project }\end{array}$ & $\begin{array}{c}\text { Social } \\
\text { product }\end{array}$ & Support & Others & Multiple & Total \\
\hline 1 & $81 \%$ & $6 \%$ & $0 \%$ & $6 \%$ & $0 \%$ & $0 \%$ & $6 \%$ & $0 \%$ & $0 \%$ & $100 \%$ \\
\hline 2 & $64 \%$ & $7 \%$ & $14 \%$ & $7 \%$ & $0 \%$ & $4 \%$ & $0 \%$ & $0 \%$ & $4 \%$ & $100 \%$ \\
\hline 3 & $50 \%$ & $7 \%$ & $0 \%$ & $0 \%$ & $43 \%$ & $0 \%$ & $0 \%$ & $0 \%$ & $0 \%$ & $100 \%$ \\
\hline 4 & $50 \%$ & $0 \%$ & $0 \%$ & $6 \%$ & $22 \%$ & $0 \%$ & $17 \%$ & $0 \%$ & $6 \%$ & $100 \%$ \\
\hline 5 & $0 \%$ & $0 \%$ & $0 \%$ & $0 \%$ & $33 \%$ & $0 \%$ & $17 \%$ & $0 \%$ & $50 \%$ & $100 \%$ \\
\hline 6 & $75 \%$ & $0 \%$ & $0 \%$ & $13 \%$ & $0 \%$ & $0 \%$ & $13 \%$ & $0 \%$ & $0 \%$ & $100 \%$ \\
\hline 7 & $37 \%$ & $0 \%$ & $0 \%$ & $11 \%$ & $42 \%$ & $0 \%$ & $0 \%$ & $0 \%$ & $11 \%$ & $100 \%$ \\
\hline 8 & $50 \%$ & $0 \%$ & $0 \%$ & $33 \%$ & $17 \%$ & $0 \%$ & $0 \%$ & $0 \%$ & $0 \%$ & $100 \%$ \\
\hline 9 & $66 \%$ & $2 \%$ & $5 \%$ & $5 \%$ & $15 \%$ & $0 \%$ & $2 \%$ & $2 \%$ & $2 \%$ & $100 \%$ \\
\hline 10 & $75 \%$ & $0 \%$ & $0 \%$ & $0 \%$ & $25 \%$ & $0 \%$ & $0 \%$ & $0 \%$ & $0 \%$ & $100 \%$ \\
\hline 11 & $79 \%$ & $0 \%$ & $2 \%$ & $0 \%$ & $15 \%$ & $0 \%$ & $2 \%$ & $2 \%$ & $0 \%$ & $100 \%$ \\
\hline 12 & $81 \%$ & $0 \%$ & $0 \%$ & $0 \%$ & $11 \%$ & $0 \%$ & $3 \%$ & $0 \%$ & $5 \%$ & $100 \%$ \\
\hline 13 & $57 \%$ & $5 \%$ & $10 \%$ & $10 \%$ & $19 \%$ & $0 \%$ & $0 \%$ & $0 \%$ & $0 \%$ & $100 \%$ \\
\hline 14 & $40 \%$ & $13 \%$ & $5 \%$ & $3 \%$ & $20 \%$ & $0 \%$ & $5 \%$ & $8 \%$ & $8 \%$ & $100 \%$ \\
\hline 15 & $88 \%$ & $4 \%$ & $0 \%$ & $4 \%$ & $4 \%$ & $0 \%$ & $0 \%$ & $0 \%$ & $0 \%$ & $100 \%$ \\
\hline 16 & $91 \%$ & $0 \%$ & $2 \%$ & $2 \%$ & $5 \%$ & $0 \%$ & $0 \%$ & $0 \%$ & $0 \%$ & $100 \%$ \\
\hline 17 & $67 \%$ & $8 \%$ & $1 \%$ & $1 \%$ & $19 \%$ & $0 \%$ & $0 \%$ & $0 \%$ & $3 \%$ & $100 \%$ \\
\hline 18 & $74 \%$ & $5 \%$ & $0 \%$ & $0 \%$ & $16 \%$ & $0 \%$ & $0 \%$ & $0 \%$ & $5 \%$ & $100 \%$ \\
\hline 19 & $70 \%$ & $0 \%$ & $0 \%$ & $0 \%$ & $30 \%$ & $0 \%$ & $0 \%$ & $0 \%$ & $0 \%$ & $100 \%$ \\
\hline 20 & $67 \%$ & $0 \%$ & $8 \%$ & $0 \%$ & $22 \%$ & $0 \%$ & $0 \%$ & $3 \%$ & $0 \%$ & $100 \%$ \\
\hline 21 & $62 \%$ & $6 \%$ & $3 \%$ & $0 \%$ & $12 \%$ & $9 \%$ & $0 \%$ & $3 \%$ & $6 \%$ & $100 \%$ \\
\hline 22 & $100 \%$ & $0 \%$ & $0 \%$ & $0 \%$ & $0 \%$ & $0 \%$ & $0 \%$ & $0 \%$ & $0 \%$ & $100 \%$ \\
\hline 23 & $100 \%$ & $0 \%$ & $0 \%$ & $0 \%$ & $0 \%$ & $0 \%$ & $0 \%$ & $0 \%$ & $0 \%$ & $100 \%$ \\
\hline 24 & $86 \%$ & $8 \%$ & $0 \%$ & $0 \%$ & $4 \%$ & $0 \%$ & $0 \%$ & $0 \%$ & $2 \%$ & $100 \%$ \\
\hline 25 & $55 \%$ & $9 \%$ & $0 \%$ & $0 \%$ & $27 \%$ & $0 \%$ & $0 \%$ & $0 \%$ & $9 \%$ & $100 \%$ \\
\hline 26 & $84 \%$ & $9 \%$ & $2 \%$ & $0 \%$ & $2 \%$ & $0 \%$ & $2 \%$ & $0 \%$ & $2 \%$ & $100 \%$ \\
\hline 27 & $19 \%$ & $1 \%$ & $0 \%$ & $0 \%$ & $79 \%$ & $0 \%$ & $0 \%$ & $1 \%$ & $0 \%$ & $100 \%$ \\
\hline 28 & $47 \%$ & $26 \%$ & $0 \%$ & $6 \%$ & $15 \%$ & $0 \%$ & $0 \%$ & $3 \%$ & $3 \%$ & $100 \%$ \\
\hline 29 & $71 \%$ & $3 \%$ & $0 \%$ & $0 \%$ & $20 \%$ & $0 \%$ & $0 \%$ & $6 \%$ & $0 \%$ & $100 \%$ \\
\hline 30 & $39 \%$ & $16 \%$ & $0 \%$ & $3 \%$ & $31 \%$ & $0 \%$ & $3 \%$ & $6 \%$ & $3 \%$ & $100 \%$ \\
\hline 31 & $62 \%$ & $0 \%$ & $3 \%$ & $3 \%$ & $21 \%$ & $0 \%$ & $6 \%$ & $3 \%$ & $3 \%$ & $100 \%$ \\
\hline Total & $63 \%$ & $6 \%$ & $2 \%$ & $2 \%$ & $21 \%$ & $0 \%$ & $2 \%$ & $2 \%$ & $3 \%$ & $100 \%$ \\
\hline
\end{tabular}


Table 6. Analysis of social investment information in paragraphs under analysis

\begin{tabular}{|c|c|c|c|c|c|c|}
\hline \multirow[b]{2}{*}{ Company } & \multicolumn{2}{|c|}{ Number of beneficiaries } & \multicolumn{2}{|c|}{ Investment value } & \multicolumn{2}{|c|}{ Use of tax benefits } \\
\hline & $\begin{array}{c}\text { Not } \\
\text { informed }\end{array}$ & Informed & $\begin{array}{c}\text { Not } \\
\text { informed }\end{array}$ & Informed & $\begin{array}{c}\text { Not } \\
\text { informed }\end{array}$ & Informed \\
\hline 1 & $87 \%$ & $13 \%$ & $69 \%$ & $31 \%$ & $94 \%$ & $6 \%$ \\
\hline 2 & $79 \%$ & $21 \%$ & $64 \%$ & $36 \%$ & $86 \%$ & $14 \%$ \\
\hline 3 & $36 \%$ & $64 \%$ & $93 \%$ & $7 \%$ & $100 \%$ & $0 \%$ \\
\hline 4 & $89 \%$ & $11 \%$ & $100 \%$ & $0 \%$ & $100 \%$ & $0 \%$ \\
\hline 5 & $83 \%$ & $17 \%$ & $67 \%$ & $33 \%$ & $83 \%$ & $17 \%$ \\
\hline 6 & $50 \%$ & $50 \%$ & $87 \%$ & $13 \%$ & $75 \%$ & $25 \%$ \\
\hline 7 & $42 \%$ & $58 \%$ & $89 \%$ & $11 \%$ & $95 \%$ & $5 \%$ \\
\hline 8 & $100 \%$ & $0 \%$ & $100 \%$ & $0 \%$ & $100 \%$ & $0 \%$ \\
\hline 9 & $80 \%$ & $20 \%$ & $61 \%$ & $39 \%$ & $87 \%$ & $13 \%$ \\
\hline 10 & $44 \%$ & $56 \%$ & $87 \%$ & $13 \%$ & $100 \%$ & $0 \%$ \\
\hline 11 & $83 \%$ & $17 \%$ & $68 \%$ & $32 \%$ & $98 \%$ & $2 \%$ \\
\hline 12 & $59 \%$ & $41 \%$ & $73 \%$ & $27 \%$ & $100 \%$ & $0 \%$ \\
\hline 13 & $90 \%$ & $10 \%$ & $95 \%$ & $5 \%$ & $90 \%$ & $10 \%$ \\
\hline 14 & $72 \%$ & $28 \%$ & $92 \%$ & $8 \%$ & $95 \%$ & $5 \%$ \\
\hline 15 & $92 \%$ & $8 \%$ & $68 \%$ & $32 \%$ & $80 \%$ & $20 \%$ \\
\hline 16 & $78 \%$ & $22 \%$ & $76 \%$ & $24 \%$ & $93 \%$ & $7 \%$ \\
\hline 17 & $85 \%$ & $15 \%$ & $99 \%$ & $1 \%$ & $98 \%$ & $2 \%$ \\
\hline 18 & $79 \%$ & $21 \%$ & $63 \%$ & $37 \%$ & $89 \%$ & $11 \%$ \\
\hline 19 & $90 \%$ & $10 \%$ & $70 \%$ & $30 \%$ & $70 \%$ & $30 \%$ \\
\hline 20 & $86 \%$ & $14 \%$ & $83 \%$ & $17 \%$ & $100 \%$ & $0 \%$ \\
\hline 21 & $65 \%$ & $35 \%$ & $68 \%$ & $32 \%$ & $79 \%$ & $21 \%$ \\
\hline 22 & $100 \%$ & $0 \%$ & $33 \%$ & $67 \%$ & $67 \%$ & $33 \%$ \\
\hline 23 & $71 \%$ & $29 \%$ & $96 \%$ & $4 \%$ & $96 \%$ & $4 \%$ \\
\hline 24 & $88 \%$ & $12 \%$ & $80 \%$ & $20 \%$ & $98 \%$ & $2 \%$ \\
\hline 25 & $55 \%$ & $45 \%$ & $82 \%$ & $18 \%$ & $73 \%$ & $27 \%$ \\
\hline 26 & $67 \%$ & $33 \%$ & $82 \%$ & $18 \%$ & $91 \%$ & $9 \%$ \\
\hline 27 & $97 \%$ & $3 \%$ & $99 \%$ & $1 \%$ & $98 \%$ & $2 \%$ \\
\hline 28 & $74 \%$ & $26 \%$ & $85 \%$ & $15 \%$ & $97 \%$ & $3 \%$ \\
\hline 29 & $66 \%$ & $34 \%$ & $83 \%$ & $17 \%$ & $91 \%$ & $9 \%$ \\
\hline 30 & $80 \%$ & $20 \%$ & $79 \%$ & $21 \%$ & $95 \%$ & $5 \%$ \\
\hline 31 & $74 \%$ & $26 \%$ & $88 \%$ & $12 \%$ & $85 \%$ & $15 \%$ \\
\hline
\end{tabular}

